\title{
The Effect of e-Learning Strategy at Primary School Level on Understanding Structure and States of Matter
}

\author{
Ines Nuić ${ }^{1 *}$, Saša Aleksej Glažar ${ }^{2}$ \\ ${ }^{1}$ University of Sarajevo, BOSNIA AND HERZEGOVINA \\ 2 University of Ljubljana, SLOVENIA
}

Received 23 May 2019 - Revised 15 November 2019 - Accepted 21 November 2019

\begin{abstract}
E-learning strategies for the teaching unit Structure and States of Matter were developed. Students' achievements and the percentages of misconceptions were compared between experimental groups taught using web-based learning material (WBLM) used as homework after conventional teaching at school (EG1), and at school settings (EG2) with the control group (CG) taught with the teacher-centred approach. The results indicated that WBLM has potential in teaching since EG1 and EG2 students had higher achievements than CG students did on tests of knowledge. Appropriate statistical procedures were used to control the effects of students' verbal and nonverbal intelligence, as well as their prior knowledge regarding the Particulate Nature of Matter. Certain misconceptions were also revealed in all groups of students, mostly related to transferring macroscopic properties to submicroscopic particles.
\end{abstract}

Keywords: structure and states of matter, web-based learning material, students' achievements, misconception, macroscopic level, submicroscopic level

\section{BACKGROUND}

The idea behind this research stems from the difficulties regarding the understanding of the particulate nature of matter (PNM) noted at the secondary school level, and also at the university level with chemistry and physics students. These concepts are taught at the primary school level within Physics and Chemistry, so the new e-learning material Structure and States of Matter, containing macroscopic and submicroscopic levels of representation, was introduced at the $8^{\text {th }}$ grade primary school level. The aim was to examine its effects on improving students' understanding by reducing the occurrence of misconceptions about these basic chemical concepts.

Studies on understanding chemical phenomena imply that instruction should emphasise the multilevel of their representation (Al-Balushi \& Al-Harthy, 2015) in order to make prerequisites for their full understanding (Treagust, 2018). Multilevel, also called the chemistry triplet (Talanquer, 2011), is described by Johnstone (1982). Chemical knowledge comprises 'at least three levels', different but interconnected: macroscopic (observable), submicroscopic (molecular), and representation (symbolic) (Johnstone, 1982; as cited in Taber, 2013). In his later papers, he represented them with a simple equilateral triangle with levels at each of its vertexes (Johnstone, 1989, 1993, 2000, as cited in Taber, 2013). Johnstone (1991, as cited in Taber, 2013) also argued that chemistry teaching is not focused on a specific vertex of the triangle but placed inside it, since students are expected to manage all three levels at once. In addition to the three levels introduced by Johnstone $(1982,1993)$, Meijer, Bulte, and Pilot (2009) introduced the concept of the meso-level, placed between the submicroscopic and macroscopic, with particle sizes between $10^{-1}$ and $10^{-7} \mathrm{~m}$.

Three levels of representation make chemical concepts more demanding for teaching, but their integration is a prerequisite for meaningful learning (Gabel, 2005). This implies that these abstract concepts should be presented to the students in different ways (Devetak \& Glažar, 2014). Before applying various teaching strategies and activities in the classroom, it is of crucial importance that the teachers themselves understand the concepts they teach on the three levels of representation and that they easily move between them (Devetak \& Glažar, 2014).

(C) 2020 by the authors; licensee Modestum Ltd., UK. This article is an open access article distributed under the terms and conditions of the Creative Commons Attribution License (http://creativecommons.org/licenses/by/4.0/). \ines_vidovic@yahoo.com (“Correspondence) $\square$ sasa.glazar@guest.arnes.si 


\section{Contribution of this paper to the literature}

- Web-based Learning Material created to integrate the macroscopic and submicroscopic levels of representation has potential in teaching fundamental chemical concepts.

- E-learning units have potential as a useful tool for the repetition and consolidation of knowledge acquired at school.

Knowledge and understanding of PNM are required in order to comprehend many concepts in chemistry, such as changes in state, the behaviour of gases, chemical reactions (Singer, Tal, \& Wu, 2003). It is recognised as one of the fundamental concepts in science education standards, as a part of scientific literacy (National Research Council, 1996) and in many scientific research papers (e.g. Adadan, 2013; Georghiades, 2000; Harrison \& Treagust, 2002; Novak, 2005; Singer et al., 2003).

Pitjeng (2014) found that the content knowledge about PNM was disappointingly low for novice graduate students in biology and chemistry. Papageorgiou, Stamovlasis, and Johnson (2010) reported that primary school teachers held similar misconceptions as their students did before the intervention they used during an in-service training course. Firmly held misconceptions and inadequate understanding about PNM between pre-service elementary science teachers were found by Aydeniz, Bilican, and Kirbulut (2017). These findings are in accordance with the studies conducted by Ramor (1992; as cited in Pitjeng, 2014) and Lutz and Potgieter (2013; as cited in Pitjeng, 2014).

Teaching strategies in chemistry should lead towards an understanding of chemical concepts, so as to include the macroscopic, submicroscopic and symbolic levels (Johnstone, 1982, 1993). Thus, multiple representations are crucial for chemistry instruction since the changes in the nature of substances take place at the submicroscopic level, unavailable to direct observation (Gilbert \& Treagust, 2009). When teaching chemical concepts, teachers mainly address and describe the macroscopic level instead of linking it to the submicroscopic (Gilbert \& Treagust, 2009). In order for students to understand specific concepts (e.g., differences in structure and states of matter), the teacher should switch to the submicroscopic level that sometimes can be a significant challenge for students to understand (Stieff, Ryu, \& Yip, 2013).

Studies demonstrated students' improved performance after instruction that emphasised the macro-submicrosymbolic level of representation (Gabel, 1993; Russell et al., 1997; Sanger, 2000), especially the submicroscopic level (Hinton \& Nakhleh, 1999; Jaber \& BouJaoude, 2012; Milenković, Segedinac, \& Hrin, 2014).

\section{The Use of Computers in the Classroom}

Conceptual understanding of chemistry can be enhanced in several ways using computer-based technologies (Ardac \& Akaygun, 2005). Computers enable synchronous representation on the macroscopic, submicroscopic and symbolic levels of representation (Russell et al., 1997); therefore, they can help students in making crossinterpretations between different levels.

One resource used to emphasise the submicro level of instruction is molecular-level animations, which can be effective if designed and presented carefully (Tasker \& Dalton, 2006). Research conducted among 16-17-year-old students resulted in students' positive attitudes toward both student-generated and expert animations of states of matter, as well as improved understanding (Yaseen \& Aubusson, 2018). Before presenting an animation, it is important to explicitly point out the key features of the displayed animation and deal with students' prior understandings (Tasker, 2016; Tasker \& Dalton, 2006).

Research has shown that students do not connect their observations on a macro level with explanations on the submicro level, which leads to developing ideas on their own, mostly the wrong ones (Barke, Hazari, \& Yitbarek, 2009). Submicroscopic concepts are invisible and more abstract than macroscopic, which makes them challenging and difficult to grasp (Al-Balushi, 2013; Al-Balushi, 2011; Al-Balushi \& Coll, 2013; Gericke \& Hagberg, 2007; Taber, 2013).

Akaygun and Jones (2013) concluded that visualisation of the particulate level can improve students' learning, especially when using computer animations of particles, which can help students to better visualise the PNM (Chang, Quintana, \& Krajcik, 2010) and enhance their conceptual understanding (Ardac \& Akaygun, 2004).

Computer animations and simulations of the processes at the submicro level are valuable in helping students visualise these processes (Tang \& Abraham, 2016; Williamson \& Abraham, 1995; Yezierski \& Birk, 2006). Dynamic visuals are favoured over static visuals (Williamson \& Abraham, 1995), since more information can be displayed with dynamic visuals, such as the velocity of particle movement in phase changes (Ardac \& Akaygun, 2005). However, merely providing dynamic visuals does not necessarily result in better understanding. Learners are faced with increased information-processing demands compared to static visuals (Lowe, 2003). The transitory nature of dynamic visuals may cause higher cognitive demands (Lewalter, 2003), so molecular representations often require 
instructional aid not provided by technology (Kozma, 2000; Sanger, 2000). Therefore, in addition to these representations, proper instruction is needed to enhance correct understanding (Sanger, 2000).

One of the resources that showed good results when applied in the chemistry classroom at the primary school level (age 12-13) is the virtual laboratory, which enables the simultaneous presentation of the macroscopic, submicroscopic, and symbolic levels of chemical concepts. (Rizman Herga, Čagran, \& Dinevski, 2016; Rizman Herga, Glažar, \& Dinevski, 2015).

It is a common practice to integrate ICT into classrooms worldwide. There are certain negative aspects of the use of ICT in schools. Instead of using computers for instructional purposes and teacher-directed student use, teachers use them for administrative activities such as writing e-mails, grading, and communication with parents (Bebbel, Russell, \& O’Dwyer, 2004). As discussed by Pribush (2015), the positive impact of technology on chemistry education is greater than its negative consequences. The positive and negative aspects of the integration of ICT into chemistry teaching and learning point to the need for careful designing (or selecting from the Internet) and applying these resources, since they can both enhance and hinder students' understanding.

When choosing resources from the Internet, teachers need to be careful because not all the available resources help promote understanding. Visual stimuli are not readily "inserted" into the learners' minds; they are filtered and then re-interpreted in congruence with the existing preconceptions (Eilks, Witteck, \& Pietzner, 2010). According to Fuchs and Woessmann (2004), who investigated the outcomes of the PISA (Programme for International Student Assessment) testing, the mere presence of technology at home does not improve learning achievements by itself; it is even negatively related to the student performance in math and reading.

\section{Concepts on Structure and States of Matter}

Traditionally, within chemistry at the primary school level (age 12-14), three states of matter are recognised and taught: solids, liquids, and gases. Scientists have found and defined other states of matter, which have been more or less acceptable within the scientific community. In some textbooks, four states of matter are mentioned (the three usual and plasma as the fourth state); some of them mention five states (Bose-Einstein condensates in addition to the previous), while other states of matter are more or less controversial (West, 2009). Papageorgiou et al. (2010) argued that "scientifically, there are no such things as "solids", "liquids", and "gases": there are substances and their states' (p. 631). For the purpose of this research, the three conventional states of matter - solid, liquid and gas - are considered.

It is common for students to experience difficulties in understanding solids, liquids, and gases. Direct sensory experience leads children to a naïve view of matter (Kind, 2004). The critical condition for understanding states of matter and transitions between them is the knowledge of particle theory of matter (Treagust et al., 2010). Children do not readily use abstract ideas about particles when it comes to properties of matter; it appears they rely solely on sensory information when reasoning about the matter, up to the age of around 14 years (Kind, 2004).

Children's naïve conceptions of matter have been a common issue within science education research in recent decades. A large proportion of the difficulties students experience when moving from everyday thinking to scientific thinking is regarded as the projection of properties from the macroscopic world to the particles (atoms and molecules) - to the submicroscopic level of representation (Andersson, 1990). Students tend to generate a hybrid macroparticulate model in which particles possess macroscopic properties (Nakhleh, Samarapungavan, \& Saglam, 2005). This is also the case when phase changes are considered (Andersson, 1990). Garcia Franco and Taber (2009) reported that students mainly show familiarity with the particle theory of matter but limited understanding of it.

Stavy and Stachel (1985) found that difficulties that children (age 5-12) experience with classifying substances into states of matter come from the fact that they perceive the solid state as something that does not easily change its shape, so objects such as sponges are harder to perceive as being solid. They also found that children classify liquids more easily than solids, perhaps because liquids are less varied in their physical characteristics. Students often fail to understand the intrinsic motion of particles in the solid state, whereas a majority of students were able to indicate particle movement in liquids and gases (Adbo \& Taber, 2009; Boz, 2006). Specific difficulties students experience with gases come from the fact that air, often used as an example, is invisible (Kind, 2004; Stavy, 1988). While children learn about solids and liquids intuitively, instruction is needed when they acquire knowledge of gases (Stavy, 1988). Students at the primary and lower secondary levels (age 12-16) rarely view air as an example of a gas. They relate gas to something harmful, but air to breathing and life (Andersson, 1990).

Findings from Slapničar, Devetak, Glažar, and Pavlin (2017) suggest that there was no significant difference between the most common misconceptions held by different age groups (12-, 14-, and 16-year-old students) regarding states of matter with respect to water and air. Certain misconceptions related to the states of matter held by primary school students are also reported by Slapničar, Tompa, Glažar, and Devetak (2018). 
One of the first studies on children's conceptions about changes in states of matter (melting, evaporation, and condensation) was performed by Osborne and Cosgrove in 1983. They uncovered a number of non-scientific conceptions among children 12-17 years old. Some of them persisted even after teaching (Tytler, 2000), such as air being in the bubbles formed when water is heated.

The importance of the PNM concept in science education has been highlighted in many research studies in the past several decades (Gabel, 1993; Harrison \& Treagust, 2002; Novick \& Nussbaum, 1978; Nyachwaya et al., 2011; Osborne \& Cosgrove, 1983; Tang \& Abraham, 2016). Tang and Abraham (2016) considered this topic as one of the most difficult to learn because it includes logical operations at the level that students are not able to be in personal contact with - the level of atoms and molecules.

\section{E-learning}

E-learning is an educational strategy that has shown good results in science education. Clark and Mayer (2011) define e-learning as instruction delivered on a digital device such as a desktop or laptop computer or a mobile device that is intended to support learning. They differentiated two forms of e-learning: asynchronous (self-learning available upon demand) and synchronous (instructor-led e-learning presented at a fixed time).

Effects of e-learning include an increase in students' motivation (especially for low-achieving students), engagement and attendance. Some meta-analyses have found that learning results are to some degree enhanced with a combined approach: e-learning and face-to-face (Means, Toyama, Murphy, Bakia, \& Jones, 2009; Roblyer \& Doering, 2009; as cited in Olson et al., 2011).

The important assumption of the constructivist learning theory is that the learner acquires knowledge by integrating new information with the existing; in this process, the key element is learners' active participation. Bodner (1986) summarized the constructivist theory in this sentence: "Knowledge is constructed in the mind of the learner" (Bodner, 1986, p. 873). According to Koohang, Riley, Smith, and Schreurs (2009, p. 91), constructivist learning theory is "a good fit for e-learning because it ensures learning among learners". Constructivism is also useful in explaining students' misconceptions in science and why they are so hard to change into scientifically accepted conceptions. The only way that an existing idea could be replaced is by constructing the new idea that better explains students' experiences (Bodner, 1986).

Ural and Ercan (2015) examined the effects of the use of web-based educational software, enriched with concept maps used to teach Structure and Properties of Matter, on the academic achievement of $7^{\text {th }}$-grade students in Turkey. The results of their study showed that these materials had a positive impact on students' academic achievements for three reasons: (1) web-assisted applications provide limitless time for the replaying option and they are suitable for an individual's learning speed, unlike the traditional learning environment; (2) rich audio-visual content has positive impact on students' learning, as well as the fact that (3) this learning material has been designed with meaningful learning in mind - learning that requires the connection of new knowledge with the previously acquired knowledge.

Stern, Barnea, and Shauli (2008) evaluated the effect of a dynamic software simulation on the understanding of the kinetic molecular theory among $7^{\text {th }}$-grade students. Their results indicated that students in the experimental group scored significantly higher and showed an improved understanding of the differences in arrangement and motion of molecules in the three states of matter compared to the students in the control group.

The application of e-learning is not limited to primary and secondary schools. Potter and Overton (2006) designed a learning resource for chemistry and presented it to university students. The results of their study showed that students responded positively to it.

Ercan, Ural, and Özateş (2016) pointed out that students favour web-based learning because of its powerful visual form, the chance to learn at their own pace, step-by-step, according to their learning speed, and the chance to repeat the material if necessary. Their research showed that Web-Based Learning Material (WBLM) contributed to students' positive attitudes towards chemistry, which is correlated to their academic achievement. Findings from Olakanmi (2015) suggested significantly improved achievements of students who used web-based computer simulations in their learning rate regarding chemical reactions, which implies the need for the training of chemistry teachers to use such materials.

\section{RESEARCH PROBLEM}

The education system in Bosnia and Herzegovina $(\mathrm{B} \& \mathrm{H})$ is a reflection of the internal organisation of the state. $\mathrm{B} \& \mathrm{H}$ is constituted of two entities (Federation of Bosnia and Herzegovina and Republic of Srpska) and one district (District Brčko). Consequently, there are three valid curricula, which are the same with regard to their structure and teaching methods. Regarding the teaching content, there are certain differences between the curricula, especially within the national groups of teaching subjects (Ibrahimović, 2015). The reform from eight-year-long to nine-year- 
long primary education started in 2004, but they were not conducted at the same time and systematically in the entire country. Students now enrol primary school at the age of 6 and complete the $9^{\text {th }}$ grade at the age of 15 . Another current paradox of the B\&H education system is two schools under one roof, which refer to some primary schools in the Federation of Bosnia and Herzegovina in which students are segregated by their nationality. Even though these schools have been declared to be unconstitutional, they continue to operate.

According to the Curriculum Framework for nine-year primary school education in the Federation of Bosnia and Herzegovina, the basics of states of matter are taught within My environment in the $2^{\text {nd }}$ grade (age 7-8; students should 'identify different states of matter ${ }^{1}$ ). In the $5^{\text {th }}$ grade (age 10-11) within Science, the states of matter are taught again, including phase changes ('through experiments, students should gain knowledge on the transition from one state of matter to another' 2). Within Physics in the 7th grade (age 12-13), students learn about the structure of matter and states of matter at the submicroscopic level. Within Chemistry in the $8^{\text {th }}$ grade (age 13-14), students learn again about the structure and states of matter at the macroscopic and submicroscopic levels, while the symbolic is introduced later.

The research on students' misconceptions, their sources and potential ways to overcome them was driven by a number of students' difficulties that were diagnosed in the written part of chemistry exams after enrolling in the university study of chemistry. Those difficulties were noted even later, at the university level ( $1^{\text {st }}$ and $2^{\text {nd }}$ year) (Gojak et al., 2012). The idea for this research came from the need for investigating whether these difficulties partially arise from primary education when students start to learn fundamental chemical concepts. The purpose of this research is to investigate the effects of e-learning on the students' understanding of the structure and states of matter on the submicro level.

\section{Research Methodology}

The study employed a quasi-experimental research approach with a non-randomized pre-test and post-test comparison group. It was performed in compliance with the relevant laws and with the parents' and school principals' permissions. Safety precautions regarding information technology equipment were taken into consideration. The study was implemented by the researcher and a cooperative $8^{\text {th }}$ grade chemistry teacher who was present during the class. The data obtained from the study were dealt with by the researcher, and no one else was aware of the participants' scores. The participants' identities were kept anonymous. The language of instruction was Bosnian; therefore, all materials are presented in the Bosnian language.

Four hypotheses were set: (1) students who learn using WBLM at school will have higher achievements on immediate and delayed post-tests of knowledge than students who are taught in the traditional way with the teacher-centered approach; (2) students who will use WBLM as homework material (after the teacher-centered approach) will have higher achievements on immediate and delayed post-tests of knowledge than students who will be taught with the teacher-centered approach only; (3) students who will learn using WBLM at school will have fewer misconceptions than students who will be taught with the teacher-centered approach, and (4) students who will use WBLM as homework material will have fewer misconceptions than students who were taught with the teacher-centered approach (CG).

\section{Procedure}

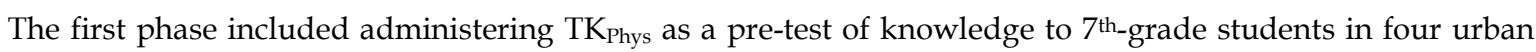
primary schools. After the summer break, the second phase of the study continued with the same students, by administering Raven's SPM and MHVS. In the introductory class, the research was presented to the experimental groups of students, including instructions for using the e-learning units on the laptop computers. Then the teaching of Structure and States of Matter (SSM) followed in all groups.

An e-learning unit was designed for this study, based on the e-learning units from the project E-kemija, ${ }^{3}$ using a tool for the design and development of electronic textbooks (eXecute) and delivered to students using PCs/laptops. They were developed based on the curriculum for the Chemistry course in $8^{\text {th }}$-grade primary school,

\footnotetext{
${ }^{1}$ Framework of a Curriculum for nine-year primary school education in Federation of Bosnia and Herzegovina, section 'Abilities and skills', p. 86.

${ }^{2}$ Framework of a Curriculum for nine-year primary school education in Federation of Bosnia and Herzegovina, section 'Knowledge', p. 246.

${ }^{3}$ The authors of the e-learning units within the project E-kemija: Bojana Boh, Iztok Devetak, Danica Dolničar, Saša A. Glažar, Andrej Godec, Samo Jamšek, Vida Mesec, Brane Pajk, Blaž Repe, Irena Sajovic, Matej Urbančič, Margareta Vrtačnik, Katarina Wissiak Grm, and Boris Zmazek. This project was implemented with the financial support of the Ministry for Education, Science and Sport of the Republic of Slovenia and European Social Fund.
} 
Table 1. E-learning unit Structure and States of Matter (SSM)

\begin{tabular}{|c|c|c|c|c|c|c|c|c|}
\hline $\begin{array}{c}\text { Slide } \\
\text { number }\end{array}$ & Title & $\begin{array}{l}\text { Word } \\
\text { count }\end{array}$ & Videos & Animations & Pictures & $\begin{array}{c}\text { DrawingsError! } \\
\text { Bookmark not } \\
\text { defined. }\end{array}$ & $\begin{array}{l}\text { Schemes/ } \\
\text { Tables }\end{array}$ & Tasks \\
\hline Slide 1 & $\begin{array}{c}\text { Substances are made of } \\
\text { particles }\end{array}$ & 233 & 1 & - & - & - & - & \\
\hline Slide 2 & Evaporation of bromine & 126 & 1 & - & - & - & 1 & \\
\hline Slide 3 & States of matter & 198 & 1 & 3 & - & - & - & \\
\hline Slide 4 & States of water & 115 & 1 & - & - & 3 & - & 1 \\
\hline Slide 5 & Summary & 167 & - & - & - & 3 & - & 4 \\
\hline Slide 6 & Tasks & 139 & - & - & 1 & - & - & 3 \\
\hline Slide 7 & Tasks & 124 & - & - & - & 8 & - & 3 \\
\hline Total & & 1102 & 4 & 3 & 1 & 14 & 1 & 11 \\
\hline
\end{tabular}

adapted and applied in teaching relevant concepts. In designing the e-learning units, both macroscopic and submicroscopic levels of representation in chemistry were included.

The e-learning unit SSM contained seven sections (slides) with an average number of 157.4 words per slide. Table 1 represents the number of selected elements on each slide.

Tasks were incorporated into most sections and at the end of the e-learning unit. Their role was to keep students' attention during learning and to give them feedback at the end of each section. No data were collected at this point.

One week after teaching, the administration of the corresponding test of knowledge (TK $\mathrm{SSM}_{\mathrm{S}}$ ) followed. Approximately three months after teaching, the repeated post-test of knowledge (TKSSM2) was administered in order to obtain insight into the retention of students' knowledge regarding the taught concepts.

\section{Participants of the Study}

The sample consisted of 111 primary school students at the end of $7^{\text {th }}$ grade (age 12-13) and at the beginning of $8^{\text {th }}$ grade (age 13-14). Some students dropped out of the sample (change of school or absence from the classroom on one or more occasions). The students were divided into one control and two experimental groups.

In the experimental group 1 (EG1, N=24) e-learning units were introduced as homework material after the usual teaching (teacher-centred approach) at school. Students received material for homework on compact discs (CDs) to work on them at home. All students from EG1 reported that they had personal computers or laptops at home. In the experimental group 2 (EG2, N=39), laptops were provided for each student. This enabled students to learn using e-learning units in the chemistry classroom under the supervision of a chemistry teacher and a researcher. The role of the chemistry teacher in EG2 was to explain the procedure that students need to follow during the class, to resolve students' possible doubts and to maintain discipline in the classroom at an adequate level. The control group (CG, N=48) was taught in the traditional way, with the teacher-centred approach. The researcher was present to ensure that the crucial concepts addressed in the e-learning units were also taught by the teacher in the control group.

Teaching strategy is not the only factor that affects students' achievements. Therefore, the following variables were selected, and their effects on the achievements in tests of knowledge are taken into account when discussing the results: students' learning preferences and attitudes related to chemistry, motivation for learning, intellectual ability, and the socio-demographic status of students.

\section{Instruments for Data Collection}

Pre-test of knowledge $\mathrm{TK}_{\mathrm{Phys}}$, a paper-and-pencil test designed for the purpose of this study, contained nine objective items regarding the macroscopic and/or submicroscopic level of representation of the states of matter. This test was used to assess the understanding of relevant concepts prior to the instructional period. The sources for the construction of this test included an instrument reported in the study of Christian and Yezierski (2012) and the Framework of Curriculum for $7^{\text {th }}$ grade Physics. Incorrect options (distracters) in the items were derived from actual student alternative conceptions gathered from the literature. Achievements on this test were used as a basis for grouping students into control and experimental groups.

Post-test of knowledge TKSSM, a paper-and-pencil test designed for the purpose of this study containing 10 items, was used to establish the effects of e-learning units on understanding concepts taught with the use of webbased learning material (WBLM). The same posttest was repeated three months after teaching in order to test the retention of students' knowledge. The items were formulated with respect to the teaching content. 
Table 2. Cronbach's alpha coefficients for instruments for data collection

\begin{tabular}{cccccc}
\hline \multicolumn{7}{c}{ Instrument } \\
\hline TK $_{\text {Phys }}$ & TK $_{\text {SSM1 }}$ & TKSSM2 $_{\text {SI }}$ & $\mathbf{Q}_{\text {ML }}$ & $\mathbf{Q}_{\mathbf{L C}}$ & $\mathbf{Q}_{\text {AC }}$ \\
\hline .596 & .711 & .529 & .988 & .745 & .845 \\
\hline
\end{tabular}

Table 3. Total descriptive statistics of TK Phys

\begin{tabular}{cccccccc}
\hline Items & Max. score & $\boldsymbol{M}$ & SD & SE & C & SIQ & Mode \\
\hline$\Sigma 9$ & 14 & 9.47 & 2.51 & 0.18 & 10 & 1.5 & 10
\end{tabular}

Legend: $M$ - mean; $S D$ - standard deviation; SE - standard error of the mean; C - median; SIQ - semi-interquartile range; Mode modus

Raven's Standard Progressive Matrices (SPM) and the Mill Hill Vocabulary Scale (MHVS) were administered by trained psychologists. The aim was to assess students' intellectual ability from a non-verbal perspective (using SPM) and to measure verbal intelligence (using MHVS), as they are predictors of academic success (Flanagan, Andrews, \& Genshaft, 1997, as cited in Kaya, Juntune, \& Stough, 2015).

In addition, the following questionnaires were administered: How I learn Chemistry (QLC; Juriševič \& Devetak, 2010), Attitude towards Chemistry (QAC; Juriševič, Vogrinc, \& Glažar (2010), Motivation for Learning (QML; Juriševič, 2010) and Socio-demographic Status of Students (QSD; adopted from TIMSS, 2007).

All instruments were piloted. The pre-test of knowledge resulted in a low value of internal consistency. The reasons for this fact could be various, such as different aspects of tested knowledge, different types of items, and a small number of items in the scale (Pallant, 2010; Tavakol \& Dennick, 2011). This does not mean that the instrument needs to be discarded; so, after the revision of scoring, we decided to keep it within the main study. The test of knowledge $\mathrm{TK}_{\mathrm{SSM}}$ resulted in acceptable internal consistency, only the revision of scoring was done.

The internal consistency of the test was evaluated using Cronbach's alpha coefficient.

Reliability analysis of instruments for collecting data resulted in generally acceptable values. Low alpha coefficients for $\mathrm{TK}_{\mathrm{Phys}}$ and $\mathrm{TK}_{\mathrm{SSM}} 2$ could be explained by different types and a limited number of test items and a rather wide range of tested knowledge. It is generally desirable for instruments to have high alphas; however, Taber (2017) claims that ' $[. .$.$] administration of instruments genuinely testing a range of distinct knowledge facets should$ not be expected to give high alphas' (p. 18). According to Dall'Oglio et al. (2010), alpha value of .5 can be acceptable for instruments containing fewer than 20 items. Some other studies also found instruments with alpha lower than .6 as acceptable (Berger \& Hänze, 2015; Bretz \& McClary, 2014; Nehring, Nowak, zu Belzen, \& Tiemann, 2015).

Based on the experiences from conducting the pilot study, an idea to explore the effect of e-learning units as homework material emerged. Therefore, two experimental groups were formed: EG1 taught with the teachercentered approach with e-learning units as homework material, and EG2 taught using e-learning units in the classroom.

The revision of e-learning units was mainly addressed to rephrasing some sentences that appeared to be unclear to students. Instead of using personal computers, laptops were provided within the main study for each student in EG2 which they have been using them in the chemistry classroom. Students were able to work individually, at their own pace.

\section{Method of Data Analysis}

For creating the database and for statistical analysis, Microsoft ${ }^{\circledR}$ Excel 2007 and IBM SPSS Statistics ${ }^{\circledR}$ for Windows (Statistical Package for the Social Sciences), version 21, were used. The analysis of data was carried out using both descriptive and inferential statistics. The post-test score was subjected to analysis of variance (One-way ANOVA, Welch test, Kruskal-Wallis H test) and analysis of covariance (ANCOVA) using pre-test, Raven's SPM and MHVS scores as covariates. The ANCOVA analysis aimed to 'statistically control' for the influence of confounding variables. A p-value of less than 0.05 was considered to be statistically significant.

\section{FINDINGS}

\section{Students' Previous Knowledge of the Relevant Science Concepts}

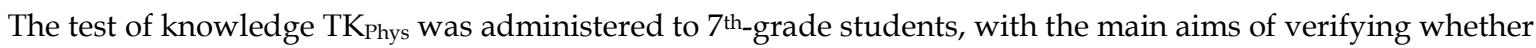
the students divided into groups are equal regarding their previous knowledge, and to reveal their potential misconceptions. The total descriptive statistics for $\mathrm{TK}_{\mathrm{Phys}}$ is represented in Table 3. 
Table 4. Descriptive statistics and analysis of variance of students' achievements on TK Phys $_{\text {s }}$

\begin{tabular}{|c|c|c|c|c|c|c|c|c|c|c|}
\hline \multirow{2}{*}{ Groups } & \multirow{2}{*}{$\begin{array}{l}\text { Max. } \\
\text { score }\end{array}$} & \multirow{2}{*}{ M } & \multirow{2}{*}{$S D$} & \multirow{2}{*}{$\begin{array}{c}\text { Mode } \\
\text { (s) }\end{array}$} & \multicolumn{2}{|c|}{ Shapiro-Wilk's test } & \multicolumn{2}{|c|}{ Levene's test } & \multicolumn{2}{|c|}{ Welch test } \\
\hline & & & & & $w$ & $p$ & $F(2,138)$ & $p$ & $F(2,83.8)$ & $p$ \\
\hline CG & \multirow{3}{*}{14} & 9.40 & 1.89 & $\begin{array}{c}8.0 \\
10.0\end{array}$ & .980 & .451 & \multirow{3}{*}{7.629} & \multirow{3}{*}{.001} & \multirow{3}{*}{1.058} & \multirow{3}{*}{.352} \\
\hline EG1 & & 9.32 & 1.04 & 10.0 & .954 & .094 & & & & \\
\hline $\mathrm{EG} 2$ & & 9.90 & 2.39 & 10.0 & .956 & .099 & & & & \\
\hline
\end{tabular}

The mean value indicates that the average students' achievements are around $67 \%$ of the maximum score. The analysis of variance performed for students' total scores on $\mathrm{TK}_{\text {Phys }}$ is presented along with descriptive statistics of students' achievements in Table 4.

Six assumptions for the one-way ANOVA were analyzed (Laerd Statistics, 2013), and five of them were met. The assumption of normality of data was met after grouping students into control and experimental groups. Levene's test indicated that the variances are not homogeneous, so the Welch test was chosen as a statistical test, which indicated that control (CG) and experimental (EG1 and EG2) groups do not differ significantly by their achievements on the pre-test of knowledge $\mathrm{TK}_{\text {Phys. }}$.

Results of this pre-test showed that the students do not differentiate the macroscopic and submicroscopic levels regarding the structure of matter and that they had not developed concepts of atoms and molecules. Students know certain phenomena about states of matter from everyday experience, but they are not able to explain them at the submicro level. Previous research showed comparable findings (Kozma \& Russell, 1997; Rappoport \& Ashkenazi, 2008; Treagust, Chittleborough, \& Mamiala, 2003). Learning submicro-macro thinking is abstract, non-observable and can be difficult for students (Gilbert \& Treagust, 2009; Taber, 2001; Tsaparlis, 1997). This implies that those concepts that include processes on the submicro level can be too demanding for $7^{\text {th }}$-grade students (age 12-13) if they were taught in the traditional way using teacher-centred teaching.

\section{Motivation for Learning}

There was a need to explore whether students from the control (CG) and experimental (EG1 and EG2) groups differed in their motivation to learn, their learning preferences, and their attitudes towards chemistry. For this purpose, the questionnaire QML (Juriševič, 2010) was administered within the main study. Nineteen elements, grouped into eight thematic groups within learning motivation, were analyzed: learning interest, attributions for success, attributions for failure, self-concept, the stimulus for learning, the importance and usefulness of learning, motivational goals and perceived difficulty (Juriševič, 2010).

Statistical analysis indicates three elements (attribution for failure - abilities $\left(p=0.029, \eta_{\mathrm{p}}^{2}=.056\right)$, attribution for failure-cause unknown ( $\left.p=0.037, \eta_{\mathrm{p}}^{2}=.052\right)$, and external enticement $\left(p=0.047, \eta_{\mathrm{p}}^{2}=.062\right)$ ) that resulted in a statistically significant difference between the groups. According to the benchmarks for eta squared reported by Cohen (1988, as cited in Lakens, 2013), the effect sizes are small or medium, so we can summarize that the groups of students are generally equal with respect to their motivation to learn and that the observed differences did not significantly affect their achievements on the tests of knowledge.

\section{Students' Learning Preferences related to Chemistry}

To determine students' learning preferences (styles), the social context they prefer when they learn and the types of learning items, the questionnaire $\mathrm{Q}_{\mathrm{LC}}$ was administered. According to the non-parametric Kruskal-Wallis H-test, there were only two segments (out of total 18) which resulted in a statistically significant difference between the groups: students' self-concept $(p=0.018)$, and preference regarding the type of items $(p=0.039)$. We can summarise that generally there was no statistically significant difference between the control and experimental groups when considering students' learning preferences, social context or the types of tasks they prefer.

\section{Students' Attitudes towards Chemistry}

Students' self-esteem and expression of their individual interest in chemistry were examined using the questionnaire $\mathrm{Q}_{\mathrm{AC}}$. Differences between the group means for these two subscales were analysed. Both subscales resulted in comparable, medium values of mean with no statistically significant difference between groups.

\section{Socio-demographic Characteristics of Students}

The secondary analysis of TIMSS 2007 in B\&H, the first and still the last TIMSS study implemented there, suggested the significant influence of some socio-demographic variables on the students' academic achievements 
Table 5. Total descriptive statistics for TKSSM1 and TKSSM2

\begin{tabular}{|c|c|c|c|c|c|c|c|c|c|c|}
\hline Group & & $M$ & $S D$ & SE & $C$ & SQR & Mode & $X_{\min }$ & $\mathbf{X}_{\max }$ & $s^{2}$ \\
\hline CG & TKssm1 & 7.41 & 2.57 & .37 & 8.38 & 1.94 & 8.5 & 1.0 & 11.5 & 6.59 \\
\hline$(n=48)$ & TKssm2 & 8.87 & 2.07 & .30 & 9.50 & 1.35 & 9.5 & 4.0 & 12.25 & 4.27 \\
\hline EG1 & TKssm1 & 8.79 & 3.03 & .62 & 9.50 & 2.63 & 4.0 & 4.0 & 13.5 & 9.19 \\
\hline$(n=24)$ & TK ${ }_{\text {SSM2 }}$ & 9.77 & 1.69 & .34 & 9.75 & 1.00 & 9.3 & 6.0 & 13.5 & 2.85 \\
\hline EG2 & TKssm1 & 10.05 & 2.30 & .37 & 10.5 & 0.75 & 11.0 & 2.0 & 13.0 & 5.30 \\
\hline$(n=39)$ & TKSsm2 & 9.90 & 2.11 & .34 & 10.5 & 1.38 & 12.0 & 3.25 & 12.0 & 4.43 \\
\hline
\end{tabular}

Legend: $M$ - mean, $S D$ - standard deviation, $\Delta M$ - difference between means, $S E$ - standard error of mean, $C$ - median, SQR semiinterquartile range, Mode - modus; $X_{\min }$ - minimum score on the test, $X_{\max }$ - maximum score on the test, $s^{2}-v_{a r i a n c e}$, Kurt coefficient of kurtosis, Skew - coefficient of skewness

Table 6. Analysis of variance for $\mathrm{TK}_{\mathrm{SSM} 1}$ and $\mathrm{TK}_{\mathrm{SSM} 2}$

\begin{tabular}{|c|c|c|c|c|c|c|c|c|c|c|}
\hline \multirow{2}{*}{$\begin{array}{c}\text { Test of } \\
\text { knowledge }\end{array}$} & \multirow{2}{*}{ Group } & \multirow{2}{*}{ M } & \multirow{2}{*}{$S D$} & \multirow{2}{*}{ SE } & \multicolumn{2}{|c|}{ Levene's test } & \multicolumn{4}{|c|}{ Analysis of variance } \\
\hline & & & & & $\boldsymbol{F}$ & $p$ & $\boldsymbol{F}$ & $p$ & $\boldsymbol{F}$ & $p$ \\
\hline & CG & 7.41 & 2.57 & .37 & & & & & \multirow{6}{*}{$8.735^{c}$} & \multirow{6}{*}{.0001} \\
\hline \multirow[t]{3}{*}{ TK } & EG1 & 8.79 & 3.03 & .62 & 4.644 & .012 & $12.610^{\mathrm{a}}$ & .0001 & & \\
\hline & EG2 & 10.05 & 2.30 & .37 & & & & & & \\
\hline & CG & 8.87 & 2.07 & .30 & & & & & & \\
\hline \multirow[t]{2}{*}{ TKssm2 } & EG1 & 9.77 & 1.69 & .34 & .817 & .444 & $3.275^{b}$ & .042 & & \\
\hline & EG2 & 9.90 & 2.11 & .34 & & & & & & \\
\hline
\end{tabular}

a - Welch test; ${ }^{b}-$ One-way ANOVA; ${ }^{c}-$ Repeated Measures ANOVA

in mathematics and science (Skelić \& Alić, 2009). The questionnaire regarding the socio-demographic status of students from TIMSS was adapted and implemented in this research. Here it should be noted that all students attend schools in the urban area. Seven of 30 total variables resulted in statistically significant differences between the groups. These variables mostly refer to the relationship of students with parents considering their homework. However, there is no visible pattern that would segregate students of any group from the other two; so, we can assume that these differences did not affect students' achievements on the tests of knowledge.

\section{Students' Knowledge of Structure and States of Matter (SSM)}

Within this teaching unit, the concepts (particles as an integral part of the substances, states of matter and phase changes) were addressed in the e-learning unit and in traditional teaching. Descriptive statistics for both the tests are presented in Table 5.

The control group (CG, teacher-centred approach) resulted in the lowest average students' achievements on TKSSM1, while EG2 (WBLM applied in the classroom) resulted in the highest achievements. The average achievements were higher on the delayed test (TKSSM2) in CG and EG1 (WBLM as homework), still highest in EG2. Median values (C) were higher on TKSSM2 for CG and EG1 and equal for EG2.

Since TKSSM was administered twice, data were analysed using the Repeated Measures (RM) ANOVA (Table 6). In addition, in order to evaluate the effectiveness of the teaching strategy, the one-way analysis of variance has been performed for each set of data (TK $\mathrm{SSM}_{\mathrm{S} 1}$ and TK $\mathrm{SSM}_{\mathrm{S} 2}$ ). The test of between-subjects effects (groups CG, EG1 and EG2) indicated that the effect of the application of WBLM on students' achievements on the tests of knowledge was statistically significant $\left(\eta_{\mathrm{p}}^{2}=.139\right)$. Multiple comparisons indicated that the statistically significant mean difference is between CG and EG2 $(\Delta M=1.83, p=.000)$.

The Welch test for TKSSM1 resulted in a statistically significant difference between the groups. The GamesHowell posthoc test pointed to the difference between CG and EG2 $(\Delta M=2.54, p=.000)$. The one-way ANOVA carried out for $\mathrm{TK}_{\mathrm{SSM} 2}$ also resulted in a statistically significant difference between the groups. However, the Scheffe posthoc test did not result in a statistically significant difference between the means. The independent sample t-test was then used to compare the means between each of the groups and resulted in the statistically significant difference between CG and EG2 $(t(85)=-2.287, p=.025)$ in favour of EG2.

\section{Analysis of Covariance (ANCOVA)}

Analysis of covariance (ANCOVA) was performed, using Raven's SPM, MHVS, and students' achievements on pre-test TK Phys, as covariates. All covariates were analysed individually.

Two assumptions for ANCOVA were not met (homogeneity of variance and normality of data). Covariates

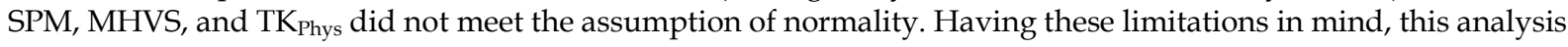


Table 7. Results of one-way ANCOVA

\begin{tabular}{|c|c|c|c|c|c|c|c|c|}
\hline \multirow{2}{*}{$\begin{array}{c}\text { Test of } \\
\text { knowledge }\end{array}$} & \multirow{2}{*}{ Covariate } & \multicolumn{5}{|c|}{ One-way ANCOVA } & \multicolumn{2}{|c|}{ Effect of covariate } \\
\hline & & $\boldsymbol{F}$ & $d f 1$ & $d f 2$ & $p$ & $\eta_{p}^{2}$ & $\boldsymbol{F}$ & $p$ \\
\hline \multirow{3}{*}{ TKssm1 } & SPM & 11.139 & 2 & 107 & .0001 & .172 & .006 & .939 \\
\hline & MHVS & 9.850 & 2 & 101 & .0001 & .163 & 51.339 & .0001 \\
\hline & TK Phys $_{\text {S }}$ & 8.890 & 2 & 107 & .0001 & .142 & 18.216 & .0001 \\
\hline \multirow{3}{*}{ TK } & SPM & 3.227 & 2 & 107 & .044 & .057 & 1.014 & .316 \\
\hline & MHVS & 1.279 & 2 & 101 & .283 & .025 & 59.580 & .0001 \\
\hline & TK Phys $_{\text {Ph }}$ & 1.881 & 2 & 107 & .157 & .034 & 23.262 & .0001 \\
\hline
\end{tabular}

was conducted but taking into consideration that it is not as informative as it would be if these assumptions were met. The results of the analysis of covariance are presented in Table 7.

The effect of SPM as a covariate was not significant in predicting the students' achievements. The role of MHVS as a covariate was statistically significant with a considerably high effect size. Still, after controlling the effect of MHVS, the difference between the groups for achievements on TKSSM1 (in favour of EG2 over EG1 and CG) was statistically significant. When taking into account the effect of $\mathrm{TK}_{\mathrm{Phys}}$, the difference was still statistically significant for TKSSM1 (in favour of EG2 over CG) and at the border of statistical significance $(p=.054$ when EG1 and CG were compared).

One-way ANCOVA performed for TKSSM2 indicated that after controlling the effects of MHVS and TK difference between the groups was not statistically significant.

\section{Analysis of Misconceptions about Structure and States of Matter (SSM)}

Certain misconceptions about Structure and States of matter occur in every group of students. The criterion for a distractor of the multiple-choice item to be selected as a misconception was the occurrence of $20 \%$ and higher, as reported in Dhindsa and Treagust (2009) and Milenković, Hrin, Segedinac, and Horvat (2016), taken from Gilbert (1977). Students in EG2 have lower or comparable occurrences of misconceptions on TKSSM1 comparing to CG and EG1, but the difference was not statistically significant $(p>.05)$. Misconceptions noted are related to the opinion that particles do not move in a solid state of matter, and to the size of particles at the micro and nano levels, which suggest that these concepts should be addressed more thoroughly.

The chi-square test for the occurrence of misconceptions on TKSSM2 resulted in a statistically significant difference between the groups. The adjusted residuals suggest that EG2 has a statistically significant lower percentage for two misconceptions related to macroscopic properties transferred to the submicroscopic world $(p=$ $.037 ; p=.035)$. CG has a higher percentage of the misconceptions also related to the transferring macroscopic properties to the submicroscopic level $(p=.023)$ and to the size of particles at nano-level $(p=.048)$. EG1 students have higher percentages of the misconception related to the transferring macroscopic properties to the submicroscopic level $(p=.035)$.

\section{CONCLUSION}

There were two approaches to teaching concepts in Structure and States of Matter using WBLM. The first approach was characterised by the usual teacher-centred teaching in the classroom and e-learning units as homework (EG1). The other approach included the application of e-learning units at school during chemistry classes, using laptop computers (EG2). The control group students were taught the usual way, with the teachercentred approach (CG).

The control of the effects of students' prior knowledge, intellectual ability (SPM) and verbal knowledge (MHVS) has enabled us to ascertain the differences in students' achievements with respect to the teaching strategies. Total scores on the immediate and delayed post-tests of knowledge were compared using appropriate statistical procedures. Students who learned using WBLM at school had statistically significant higher achievements on the post-test of knowledge administered one week after teaching than control group students. Results indicated that the retention of knowledge was also higher in EG2 since these students scored higher than CG students on delayed post-test three months after teaching, which confirms the first hypothesis.

Students who were learning using WBLM at home (EG1) also scored higher than CG students did, which is in accordance with our second hypothesis. When considering the test of knowledge applied one week after the teaching, these differences were at the edge of statistical significance after controlling the effect of TK significant in the case of delayed post-test after controlling both MHVS and TK $\mathrm{K}_{\text {Phs. }}$

The data indicated that students have certain incorrect views about SSM arising from assigning macroscopic properties to submicroscopic particles, and students' perception of the size of the particles. The percentages of 
students possessing these misconceptions are lower in EG2 than in CG and EG1, and the difference was statistically significant. These results have validated our third hypothesis. The fact that EG1 students possessed certain misconceptions in higher percentage (fourth hypothesis) we can attribute to one of the limitations of the study since we were not able to determine if EG1 students were learning using WBLM at home.

Some of the limitations of the research were revealed within the pilot study, such as limited availability of personal computers in school settings which was resolved by providing laptops to EG2 students. Furthermore, the researcher was not able to be present in each classroom for administering each instrument. On some occasions, the administration depended on the teacher. Some teachers, however, were not fully cooperative, which in turn resulted in the dismissal of some copies of the instruments as unreliable.

The teacher-centered approach is common in our schools and both teachers and students are used to it, which makes the change towards more learner-centered teaching quite demanding. However, our mission is a learnercentered school environment and this study is a step toward this goal.

Part of limitations refers to the sample itself. There was a certain number of EG1 students who reported they could not access the teaching content on compact discs, due to a "computer virus" or that "there was nothing" on $\mathrm{CD}$. We needed to discard the data gathered from these students too. Another important aspect was teachers' scepticism about the application of e-learning units. They believe that in addition to the e-learning units, the teacher needs to give some input too, so students would have material for learning in their notebooks.

It should be highlighted that the students in EG2 were learning in the classroom and their work on e-learning units was controlled by the teacher and researcher who were monitoring their progress. The EG1 students were working at home, and there was no mechanism to control if they worked as planned. This probably reflects on the students' achievements. Nevertheless, EG1 students scored higher (even though not statistically significant) than students in CG on both the immediate and delayed tests. This indicates that e-learning units have potential as a useful tool for the repetition and consolidation of knowledge acquired at school.

Since e-learning units are made considering the triple nature of representing chemical concepts, these results indicate the considerable potential of e-learning units applied both in the classroom and as homework material, with the aim to promote learning with understanding.

E-learning has been reported to have benefits in teaching and learning science in many research studies, such as that of Faulconer, Griffith, Wood, Acharyya, and Roberts (2018); Anđelković, Anđelković and Nikolić (2015); Awad (2014); Odhiambo (2010); Frailich, Kesner and Hofstein (2007). The results of this research are congruent with the published results when considering the effectiveness of the teaching strategy including WBLM applied in the classroom

A more thorough study on the implementation of e-learning units as homework assignments could be included in further studies. Providing online access to the e-learning units would be more convenient for students than using CDs; it can also be more easily tracked. This provides an opportunity to find out whether the students actually tried to access the content of e-learning units. E-learning units could be redesigned to be supported by smartphones and tablets.

The study could be deepened by including schools from rural regions. Potential variations between students in sociodemographic status might affect their achievements. It is also possible to investigate the impact of applying elearning units on students' motivation to study chemistry, their attitudes towards chemistry and their learning preferences.

Moreover, Osborne, Simon, and Collins (2003) have compiled a significant number of studies indicating that the role of the teacher and his/ her attitudes is very important in the teaching process. Since certain teachers' scepticism regarding the application of e-learning units was noted, it is possible to expand the research by exploring the influence of teachers' attitudes.

\section{REFERENCES}

Adadan, E. (2013). Using multiple representations to promote grade 11 students' scientific understanding of the particle theory of matter. Research in Science Education, 43(3), 1079-1105. https://doi.org/10.1007/s11165012-9299-9

Adbo, K., \& Taber, K. S. (2009). Learners' mental models of the particle nature of matter: A study of 16-year-old Swedish science students. International Journal of Science Education, 31(6), 757-786. https:/ / doi.org/10.1080/09500690701799383

Akaygun, S., \& Jones, L. L. (2013). Dynamic visualizations: Tools for understanding the particulate nature of matter. In G. Tsaparlis \& H. Sevian (Eds.), Concepts of matter in science education (pp. 281-300). Dordrecht, Netherlands: Springer Science + Business Media B.V. https://doi.org/10.1007/978-94-007-5914-5_13 
Al-Balushi, S. M. (2011). Students' evaluation of the credibility of scientific models that represent natural entities and phenomena. International Journal of Science and Mathematics Education, 9(3), 571-601. https:/ / doi.org/10.1007/s10763-010-9209-4

Al-Balushi, S. M. (2013). The relationship between learners' distrust of scientific models, their spatial ability, and the vividness of their mental images. International Journal of Science and Mathematics Education, 11(3), 707-732. https:/ / doi.org/10.1007/s10763-012-9360-1

Al-Balushi, S. M., \& Al-Harthy, I. S. (2015). Students' mind wandering in macroscopic and submicroscopic textual narrations and its relationship with their reading comprehension. Chemistry Education Research and Practice, 16(3), 680-688. https:/ / doi.org/10.1039/C5RP00052A

Al-Balushi, S. M., \& Coll, R. K. (2013). Exploring verbal, visual and schematic learners' static and dynamic mental images of scientific species and processes in relation to their spatial ability. International Journal of Science Education, 35(3), 460-489. https:/ / doi.org/10.1080/09500693.2012.760210

Anđelković, T., Anđelković, D., \& Nikolić, Z. (2015, September). The impact of e-learning in chemistry education. Paper presented at The Sixth International Conference on E-Learning (eLearning-2015), Belgrade, Serbia. Retrieved from http://econference.metropolitan.ac.rs/files/pdf/2015/17-Tatjana-Andjelkovic-Darko-AndjelkovicZoran-Nikolic-The-Impact-of-eLearning-in-Chemistry-Education.pdf

Andersson, B. (1990). Pupils' conceptions of matter and its transformations (age 12-16). Studies in Science Education, 18(1), 53-85. https:/ / doi.org/10.1080/03057269008559981

Ardac, D., \& Akaygun, S. (2004). Effectiveness of multimedia-based instruction that emphasizes molecular representations on students' understanding of chemical change. Journal of Research in Science Teaching, 40(4), 317-337. https:// doi.org/10.1002/tea.20005

Ardac, D., \& Akaygun, S. (2005). Using static and dynamic visuals to represent chemical change at molecular level. International Journal of Science Education, 27(11), 1269-1298. https:/ / doi.org/10.1080/09500690500102284

Awad, B. (2014). Empowerment of teaching and learning chemistry through information and communication technologies. African Journal of Chemical Education, 4(3), 34-47. Retrieved from https://www.ajol.info/index.php/ajce/article/view/104094

Aydeniz, M., Bilican, K., \& Kirbulut, Z. D. (2017). Exploring pre-service elementary science teachers' conceptual understanding of particulate nature of matter through three-tier diagnostic test. International Journal of Education in Mathematics, Science and Technology (IJEMST), 5(3), 221-234. https://doi.org/10.18404/ijemst.296036

Barke, H. D., Hazari, A., \& Yitbarek, S. (2009). Misconceptions in Chemistry: Addressing Perceptions in Chemical Education. Berlin, Germany: Springer-Verlag.

Bebbel, D., Russell, M., \& O’Dwyer, L. (2004). Measuring teachers' technology uses: Why multiple-measures are more revealing. Journal of Research on Technology in Education, 37(1), 45-63. https:/ / doi.org/10.1080/15391523.2004.10782425

Berger, R., \& Hänze, M. (2015). Impact of expert teaching quality on novice academic performance in the jigsaw cooperative learning method. International Journal of Science Education, 37(2), 294-320. https:/ / doi.org/10.1080/09500693.2014.985757

Bodner, G. M. (1986). Constructivism: a theory of knowledge. Journal of Chemical Education, 63(10), 873-878. https://doi.org/10.1021/ed063p873

Boz, Y. (2006). Turkish pupils' conceptions of the particulate nature of matter. Journal of Science Education and Technology, 15(2), 203-213. https:/ / doi.org/10.1007/s10956-006-9003-9

Bretz, S. L., \& McClary, L. (2014). Students' understandings of acid strength: how meaningful is reliability when measuring alternative conceptions? Journal of Chemical Education, 92(2), 212-219. https://doi.org/10.1021/ed5005195

Chang, H. Y., Quintana, C., \& Krajcik, J. S. (2010). The impact of designing and evaluating molecular animations on how well middle school students understand the particulate nature of matter. Science Education, 94(1), 7394. https:// doi.org/10.1002/sce.20352

Christian, B. N., \& Yezierski, E. J. (2012). Development and validation of an instrument to measure student knowledge gains for chemical and physical change for grades 6-8. Chemistry Education Research and Practice, 13(3), 384-393. https:/ / doi.org/10.1039/c2rp20041d

Clark, R. C., \& Mayer, R. E. (2011). E-learning and the science of instruction: Proven guidelines for consumers and designers of multimedia learning (3rd ed). San Francisco, CA: Pfeiffer. https://doi.org/10.1002/9781118255971 
Dall'Oglio, A. M., Rossiello, B., Coletti, M. F., Caselli, M. C., Ravà, L., Di Ciommo, V., ... Pasqualetti, P. (2010). Developmental evaluation at age 4: validity of an Italian parental questionnaire. Journal of Paediatrics and Child Health, 46(7-8), 419-426. https:/ / doi.org/10.1111/j.1440-1754.2010.01748.x

Devetak, I., \& Glažar, S. A. (2014). Educational models and differences between groups of 16-year-old students in gender, motivation, and achievements in chemistry. In I. Devetak, \& S. A. Glažar (Eds.), Learning with understanding in the chemistry classroom (pp. 209-231). Dordrecht, Netherlands: Springer Science + Business Media B.V. https:/ / doi.org/10.1007/978-94-007-4366-3_6

Eilks, I., Witteck, T., \& Pietzner, V. (2010). Using multimedia learning aids from the internet for teaching chemistry: Not as easy as it seems? In S. Rodrigues (Ed.), Multiple Literacy and Science Education: ICTs in Formal and Informal Learning Environments (pp. 49-69). Hershey, PA: Information Science Reference. Limited preview. https:/ / doi.org/10.4018/978-1-61520-690-2.ch004

Ercan, O., Ural, E., \& Özateş, D. (2016). The effect of web-assisted teaching on students' achievement in the subject of mixtures and attitudes towards chemistry. Hacettepe University Journal of Education, 31(1), 163-179. https:/ / doi.org/10.16986/HUJE.2015014089

Faulconer, E. K., Griffith, J. C., Wood, B. L., Acharyya, S., \& Roberts, D. L. (2018). A comparison of online and traditional chemistry lecture and lab. Chemistry Education Research and Practice, 19(1), 392-397. https://doi.org/10.1039/C7RP00173H

Frailich, M., Kesner, M., \& Hofstein, A. (2007). The influence of web-based chemistry learning on students' perceptions, attitudes, and achievements. Research in Science E Technological Education, 25(2), 179-197. https:/ / doi.org/10.1080/02635140701250659

Franco, G. A., \& Taber, K. S. (2009). Secondary students' thinking about familiar phenomena: Learners' explanations from a curriculum context where 'particles' is a key idea for organising teaching and learning. International Journal of Science Education, 31(14), 1917-1952. https:/ / doi.org/10.1080/09500690802307730

Fuchs, T., \& Woessmann, L. (2004). Computers and student learning: Bivariate and multivariate evidence on the availability and use of computers at home and at school. CEIS Working Paper No. 1321, 1-20. Retrieved from www.ifo.de/portal/pls/portal/docs/1/1188938.pdf

Gabel, D. (2005). Enhancing students' conceptual understanding of chemistry through integrating the macroscopic, particle, and symbolic representations of matter. In N. J. Pienta, M. M. Cooper, \& T. Greenbowe (Eds.), Chemists' Guide to Effective Teaching p. 77). Upper Saddle River, NJ: Pearson.

Gabel, D. L. (1993). Use of the particle nature of matter in developing conceptual understanding. Journal of Chemical Education, 70(3), 193-194. https://doi.org/10.1021/ed070p193

Georghiades, P. (2000). Beyond conceptual change learning in science education: focusing on transfer, durability, and metacognition. Educational Research, 42(2), 119-139. https:/ / doi.org/10.1080/001318800363773

Gericke, N. M., \& Hagberg, M. (2007). Definition of historical models of gene function and their relation to students' understanding of genetics. Science E Education, 16, 849-881. https://doi.org/10.1007/s11191-006-9064-4

Gilbert, J. K., \& Treagust, D. (Eds.). (2009). Multiple Representations in Chemical Education. Dordrecht, Netherlands: Springer Science + Business Media B.V. https:/ / doi.org/10.1007/978-1-4020-8872-8

Gojak, S., Galijašević, S., Hadžibegović, Z., Zejnilagić-Hajrić, M., Nuić, I., \& Korać, F. (2012). Integrated knowledge of physics and chemistry: Case of Physical Chemistry course. Bulletin of the Chemists and Technologists of Bosnia and Herzegovina, 38, 43-51. Retrieved from http://www.pmf.unsa.ba/hemija/glasnik/files/Issue \%2038/38\%20-\%209-Gojak.pdf

Harrison, A. G., \& Treagust, D. F. (2002). The particulate nature of matter: Challenges in understanding the submicroscopic world. In Chemical education: Towards research-based practice (pp. 189-212). Springer, Dordrecht. https://doi.org/10.1007/0-306-47977-X_9

Hinton, M. E., \& Nakhleh, M. B. (1999). Students' microscopic, macroscopic, and symbolic representations of chemical reactions. The Chemical Educator, 4, 158-167. https://doi.org/10.1007/s00897990325a

Ibrahimović, N. (2015). Osnovnoškolsko i srednjoškolsko obrazovanje u BiH: Trenutno stanje i preporuke za reforme [Primary and secondary education in BiH: Current status and recommendations for reforms]. Sarajevo: Inicijativa za monitoring evropskih integracija BiH. Retrieved from http://eu-monitoring.ba/namir-ibrahimovicosnovnoskolsko-i-srednjoskolsko-obrazovanje-u-bih-trenutno-stanje-i-preporuke-za-reforme/

Jaber, L. Z., \& BouJaoude, S. (2012). A macro-micro-symbolic teaching to promote relational understanding of chemical reactions. International Journal of Science Education, 34(7), 973-998. https:/ / doi.org/10.1080/09500693.2011.569959 
Johnstone, A. H. (1982). Macro- and micro-chemistry. School Science Review, 64(227), 377-379. Cited in Tsaparlis, G., \& Sevian, H. (2013). Introduction: Concepts of matter - Complex to teach and difficult to learn. In G. Tsaparlis and H. Sevian (Eds.), Concepts of Matter in Science Education (pp. 1-8). Dordrecht, Netherlands: Springer Science + Business Media B.V. https:/ / doi.org/10.1007/978-94-007-5914-5_1

Johnstone, A. H. (1993). The development of chemistry teaching: A changing response to changing demand. Journal of Chemical Education, 70(9), 701-705. https://doi.org/10.1021/ed070p701

Juriševič, M. (2010). UM - Vprašalnik za učence osnovne šole [UM - Questionnaire for primary school students]. In Interim Report V5-0424: Analiza dejavnikov, ki vplivajo na trajnejše znanje z razumevanjem naravoslovno-tehniških vsebin (pp. 2-5). Ljubljana: Pedagoška fakulteta Univerze v Ljubljani.

Juriševič, M., \& Devetak, I. (2010). Kako se učim kemijo [How I learn chemistry]. In Interim Report V5-0424: Analiza dejavnikov, ki vplivajo na trajnejše znanje z razumevanjem naravoslovno-tehniških vsebin (pp. 6-7). Ljubljana: Pedagoška fakulteta Univerze v Ljubljani.

Juriševič, M., Vogrinc, J., \& Glažar, S. A. (2010). Odnos do kemije [Attitude toward chemistry]. In Interim Report V50424: Analiza dejavnikov, ki vplivajo na trajnejše znanje z razumevanjem naravoslovno-tehniških vsebin (p. 8). Ljubljana: Pedagoška fakulteta Univerze v Ljubljani.

Kaya, F., Juntune, J., \& Stough, L. (2015). Intelligence and its relationship to achievement. Elementary Education Online 14(3), 1060-1078. https:/ / doi.org/10.17051/io.2015.25436

Kind, V. (2004). Beyond Appearances: Students' misconceptions about basic chemical ideas (2nd Ed.) Royal Society of Chemistry. Retrieved from http://community.nsee.us/pd/pd2007_assessment/misconceptions/Beyondappearances.pdf

Koohang, A., Riley, L., Smith, T., \& Schreurs, J. (2009). E-learning and constructivism: From theory to application. Interdisciplinary Journal of E-Learning and Learning Objects, 5(1), 91-109. https:/ / doi.org/10.28945/3321

Kozma, R. B. (2000). The use of multiple representations and the social construction of understanding in chemistry. In M. J. Jacopson \& R. B. Kozma (Eds.), Innovations in science and mathematics education (pp. 11-45). Mahwah, NJ: Lawrence Erlbaum Associates. https:// doi.org/10.4324/9781410602671

Kozma, R. B., \& Russell, J. (1997). Multimedia and understanding: Expert and novice responses to different representations of chemical phenomena. Journal of Research in Science Teaching, 34(9), 949-968. https:/ / doi.org/10.1002/(SICI)1098-2736(199711)34:9<949::AID-TEA7>3.0.CO;2-U

Laerd Statistics. (2013). One-way ANOVA in SPSS Statistics. Retrieved from https://statistics.laerd.com/spsstutorials/one-way-anova-using-spss-statistics.php

Lakens, D. (2013). Calculating and reporting effect sizes to facilitate cumulative science: A practical primer for ttests and ANOVAs. Frontiers in Psychology, 4, 1-12. https:/ / doi.org/10.3389/fpsyg.2013.00863

Lewalter, D. (2003). Cognitive strategies for learning from static and dynamic visuals. Learning and Instruction 13, 177-189. https:/ / doi.org/10.1016/S0959-4752(02)00019-1

Lowe, R. K. (2003). Animation and learning: Selective processing of information in dynamic graphics. Learning and Instruction, 13(2), 157-176. https:/ / doi.org/10.1039/C6RP00013D

Means, B., Toyama, Y., Murphy, R., Bakia, M., \& Jones, K. (2009). Evaluation of evidence-based practices in online learning: A meta-analysis and review of online learning studies. Retrieved from http://repository.alt.ac.uk/629/

Meijer, M. R., Bulte, A. M. W., \& Pilot, A. (2009). Structure-property relations between macro and micro representations: Relevant meso levels in authentic tasks. In J. K. Gilbert \& D. F. Treagust (Eds.), Multiple representations in chemical education (Models and modeling in chemical education, Vol. 4, pp. 195-213). Dordrecht, Netherlands: Springer Science + Business Media B.V. https:/ / doi.org/10.1007/978-1-4020-88728_10

Milenković, D. D., Hrin, T. N., Segedinac, M. D., \& Horvat, S. (2016). Identification of misconceptions through multiple choice tasks at municipal chemistry competition test. Journal of Subject Didactics, 1(1), 3-12. https:// doi.org/10.5281/zenodo.55468

Milenković, D. D., Segedinac, M. D., \& Hrin, T. N. (2014). Increasing high school students' chemistry performance and reducing cognitive load through an instructional strategy based on the interaction of multiple levels of knowledge representation. Journal of Chemical Education, 91(9), 1409-1416. https://doi.org/10.1021/ed400805p

Nakhleh, M. B., Samarapungavan, A., \& Saglam, Y. (2005). Middle school students' beliefs about matter. Journal of Research in Science Teaching, 42(5), 581-612. https:/ / doi.org/10.1002/ tea.20065

National Research Council (1996). National science education standards. National Academies Press. https:/ / doi.org/10.17226/4962 
Nehring, A., Nowak, K. H., zu Belzen, A. U., \& Tiemann, R. (2015). Predicting students' skills in the context of scientific inquiry with cognitive, motivational, and sociodemographic variables. International Journal of Science Education, 37(9), 1343-1363. https:/ / doi.org/10.1080/09500693.2015.1035358

Novak, J. (2005). Results and implications of a 12-year longitudinal study of science concept learning. Research in Science Education, 35(1), 23-40. https:/ / doi.org/10.1007/s11165-004-3431-4

Novick, S., \& Nussbaum, J. (1978). Junior high school pupils' understanding of the particulate nature of matter: An interview study. Science Education, 62(3), 273-281. https://doi.org/10.1002/sce.3730620303

Nyachwaya, J. M., Mohamed, A. R., Roehrig, G. H., Wood, N. B., Kern, A. L., \& Schneider, J. L. (2011). The development of an open-ended drawing tool: An alternative diagnostic tool for assessing students' understanding of the particulate nature of matter. Chemistry Education Research and Practice, 12, 121-132. https:// doi.org/10.1039/C1RP90017J

Odhiambo, S. O. (2010). The impact of e-learning on academic performance: A case study of group learning sets (Master Thesis). Nairobi, Kenya: University of Nairobi.

Olakanmi, E. E. (2015). The effects of a web-based computer simulation on students' conceptual understanding of rate of reaction and attitude towards chemistry. Journal of Baltic Science Education, 14(5), 627-640.

Olson, J., Codde, J., deMaagd, K., Tarkleson, E., Sinclair, J., Yook, S., \& Egidio, R. (2011). An Analysis of e-Learning Impacts $\mathcal{E}$ Best Practices in Developing Countries. Michigan State University. Retrieved from http:/ / cas.msu.edu/wp-content/uploads/2013/09/E-Learning-White-Paper_oct-2011.pdf

Osborne, J., Simon, S., \& Collins, S. (2003). Attitudes towards science: A review of the literature and its implications. International Journal of Science Education 25(9), 1049-1079. https:/ / doi.org/10.1080/0950069032000032199

Osborne, R. J., \& Cosgrove, M. M. (1983). Children's conceptions of the changes of state of water. Journal of Research in Science Teaching, 20(9), 825-838. https:/ / doi.org/10.1002/tea.3660200905

Pallant, J. (2010). SPSS Survival manual - A step by step guide to data analysis using SPSS (4th ed.) Berkshire, U. K.: McGraw-Hill.

Papageorgiou, G., Stamovlasis, D., \& Johnson, P. M. (2010). Primary teachers' particle ideas and explanations of physical phenomena: Effect of an in-service training course. International Journal of Science Education, 32(5), 629-652. https:/ / doi.org/10.1080/09500690902738016

Pitjeng, P. (2014). Novice unqualified graduate science teachers' topic specific pedagogical content knowledge, content knowledge and their beliefs about teaching. In H. Venkat, M. Rollnick, J. Loughran, \& M. Askew (Eds.), Exploring mathematics and science teachers' knowledge: Windows into teacher's thinking (pp. 65-83). London, U. K.: Routledge. https:/ / doi.org/10.4324/9781315883090

Potter, N. M., \& Overton, T. L. (2006). Chemistry in sport: Context-based e-learning in chemistry. Chemistry Education Research and Practice, 7(3), 195-202. https:/ / doi.org/10.1039/B6RP90008A

Pribush, R. A. (2015). Impact of technology on chemistry instruction. In M.V. Orna (Ed.), Sputnik to Smartphones: A Half-Century of Chemistry Education - ACS Symposium Series 1208 (pp. 155-194). Washington, D.C.: American Chemical Society. https:/ / doi.org/10.1021/bk-2015-1208.ch010

Rappoport, L. T., \& Ashkenazi, G. (2008). Connecting levels of representation: Emergent versus submergent perspective. International Journal of Science Education, 30(12), 1585-1603. https:/ / doi.org/10.1080/09500690701447405

Rizman Herga, N., Čagran, B., \& Dinevski, D. (2016). Virtual laboratory in the role of dynamic visualisation for better understanding of chemistry in primary school. Eurasia Journal of Mathematics, Science $\mathcal{E}$ Technology Education, 12(3), 593-608. https://doi.org/10.12973/eurasia.2016.1224a

Rizman Herga, N., Glažar, S. A., \& Dinevski, D. (2015). Dynamic visualization in the virtual laboratory enhances the fundamental understanding of chemical concepts. Journal of Baltic Science Education 14(3), 351-365. Retrieved from http://www.scientiasocialis.lt/jbse/files/pdf/vol14/351-365.Herga_JBSE_Vol.14_ No.3.pdf

Russell, J. W., Kozma, R. B., Jones, T., Wykoff, J., Marx, N., \& Davis, J. (1997). Use of simultaneous-synchronized macroscopic, microscopic, and symbolic representations to enhance the teaching and learning of chemical concepts. Journal of Chemical Education, 74(3), 330-334. https:/ / doi.org/10.1021/ed074p330

Sanger, M. J. (2000). Using particulate drawings to determine and improve students' conceptions of pure substances and mixtures. Journal of Chemical Education, 77(6), 762-766. https:/ / doi.org/10.1021/ed077p762

Singer, J. E., Tal, R., \& Wu, H. K. (2003). Students' understanding of the particulate nature of matter. School Science and Mathematics, 103(1), 28-44. https:/ / doi.org/10.1111/j.1949-8594.2003.tb18111.x 
Skelić, Dž., \& Alić, A. (2009). Postignuća učenika u kontekstu porodičnih prilika [Student achievements in the context of family situation]. In N. Suzić, Ž. Saničanin, A. Alić, Dž. Skelić, D. Rukavina, E. Alibegović Goro, Ž. Džumhur, S. Šahinović Batista, I. Milinković Rosić, V. Mešić, \& A. Ibraković (Eds.), Sekundarna analiza TIMSS 2007 u Bosni i Hercegovini (pp. 235-272). Sarajevo, Bosna i Hercegovina: Agencija za predškolsko, osnovno i srednje obrazovanje.

Slapničar, M., Devetak, I., Glažar, S. A., \& Pavlin, J. (2017). Identification of the understanding of the states of matter of water and air among Slovenian students aged 12, 14 and 16 through solving authentic tasks. Journal of Baltic Science Education, 16(3), 308-323. Retrieved from http:/ / oaji.net/articles/2017/987-1497963826.pdf

Slapničar, M., Tompa, V., Glažar, S. A., \& Devetak, I. (2018). Fourteen-year-old students' misconceptions regarding the sub-micro and symbolic levels of specific chemical concepts. Journal of Baltic Science Education, 17(4), 620632.

Stavy, R. (1988). Children's conception of gas. International Journal of Science Education, 10(5), 553-560. https://doi.org/10.1080/0950069880100508

Stavy, R., \& Stachel, D. (1985). Children's ideas about 'solid' and 'liquid'. European Journal of Science Education, 7(4), 407-421. https:// doi.org/10.1080/0140528850070409

Stern, L., Barnea, N., \& Shauli, S. (2008). The effect of a computerized simulation on middle school students' understanding of the kinetic molecular theory. Journal of Science Education and Technology, 17, 305-315. https:/ / doi.org/10.1007/s10956-008-9100-Z

Stieff, M., Ryu, M., \& Yip, J. C. (2013). Speaking across levels - Generating and addressing levels confusion in discourse. Chemistry Education Research and Practice, 14(4), 376-389. https:/ / doi.org/10.1039/C3RP20158A

Taber, K. S. (2001). Building the structural concepts of chemistry: Some considerations from educational research. Chemistry Education Research and Practice, 2(2), 123-158. https:/ / doi.org/10.1039/b1rp90014e

Taber, K. S. (2013). Revisiting the chemistry triplet: drawing upon the nature of chemical knowledge and the psychology of learning to inform chemistry education. Chemistry Education Research and Practice, 14(2), 156168. https:// doi.org/10.1039/c3rp00012e

Taber, K. S. (2017). The use of Cronbach's alpha when developing and reporting research instruments in science education. Research in Science Education (online first). https:/ / doi.org/10.1007/s11165-016-9602-2

Talanquer, V. (2011). Macro, submicro, and symbolic: The many faces of the chemistry “triplet". International Journal of Science Education, 33(2), 179-195. https:/ / doi.org/10.1080/09500690903386435

Tang, H., \& Abraham, M. R. (2016). Effect of computer simulations at the particulate and macroscopic levels on students' understanding of the particulate nature of matter. Journal of Chemical Education, 93(1), 31-38. https://doi.org/10.1021/acs.jchemed.5b00599

Tasker, R. (2016). ConfChem Conference on interactive visualizations for chemistry teaching and learning: Research into practice - Visualizing the molecular world for a deep understanding of chemistry. Journal of Chemical Education, 93(6), 1152-1153. https:/ / doi.org/10.1021/acs.jchemed.5b00824

Tasker, R., \& Dalton, R. (2006). Research into practice: Visualisation of the molecular world using animations. Chemistry Education Research and Practice, 7(2), 141-159. https:/ / doi.org/10.1039/B5RP90020D

Tavakol, M., \& Dennick, R. (2011). Making sense of Cronbach's alpha. International journal of medical education, 2, 5355. https://doi.org/10.5116/ijme.4dfb.8dfd

Treagust, D. F. (2018). The importance of multiple representations for teaching and learning science. In: M. Shelley, \& S. A. Kiray (Eds.), Education Research Highlights in Mathematics, Science and Technology 2018. Ames, Iowa: ISRES Publishing.

Treagust, D. F., Chandrasegaran, A. L., Crowley, J., Yung, B. H. W., Cheong, I. P. A., \& Othman, J. (2010). Evaluating students' understanding of kinetic particle theory concepts relating to the states of matter, changes of state and diffusion: A cross-national study. International Journal of Science and Mathematics Education, 8, 141-164. https://doi.org/10.1007/s10763-009-9166-y

Treagust, D., Chittleborough, G., \& Mamiala, T. (2003). The role of submicroscopic and symbolic representations in chemical explanations. International Journal of Science Education, 25(11), 1353-1368. https:/ / doi.org/10.1080/0950069032000070306

Tsaparlis, G. (1997). Atomic and molecular structure in chemical education: A critical analysis from various perspectives of science education. Journal of Chemical Education, 74(8), 922. https://doi.org/10.1021/ed074p922 
Tytler, R. (2000). A comparison of year 1 and year 6 students' conceptions of evaporation and condensation: Dimensions of conceptual progression. International Journal of Science Education, 22(5), 447-467. https:/ / doi.org/10.1080/095006900289723

Ural, E., \& Ercan, O. (2015). The effects of web-based educational software enriched by concept maps on learning of structure and properties of matter. Journal of Baltic Science Education, 14(1), 7-19. Retrieved from http:/ / www.scientiasocialis.lt/jbse/files/pdf/vol14/7-19.Ural_JBSE_Vol.14_No.1.pdf

West, K. (2009). States of matter: Gases, liquids, and solids. New York, NY: Infobase Publishing.

Williamson, V. M., \& Abraham, M. R. (1995). The effects of computer animation on the particulate mental models of college chemistry students. Journal of Research in Science Teaching, 32(5), 521-534. https://doi.org/10.1002/tea.3660320508

Yaseen, Z., \& Aubusson, P. (2018). Exploring student-generated animations, combined with a representational pedagogy, as a tool for learning in chemistry. Research in Science Education, 1-20. https:/ / doi.org/10.1007/s11165-018-9700-4

Yezierski, E. J., \& Birk, J. P. (2006). Misconceptions about the particulate nature of matter: Using animations to close the gender gap. Journal of Chemical Education, 83(6), 954-960. https://doi.org/10.1021/ed083p954

\section{http://www.ejmste.com}

